\title{
Does HIV impact susceptibility to COVID-19 (SARS-CoV-2) infection and pathology? A review of the current literature
}

\section{Running Title: HIV and susceptibility to COVID-19}

\author{
Elnara Aghakishiyeva ${ }^{\mathrm{a}}$, Derek Macallan ${ }^{\mathrm{a}, \mathrm{b}}$
}

a. Institute for Infection \& Immunity, St George's, University of London, London, UK

b. Infection Care Group, St George's University Hospitals NHS Foundation Trust, London, UK

\section{For Correspondence}

Prof Derek Macallan

Institute for Infection \& Immunity,

St George's, University of London,

London, SW17 ORE. UK

macallan@sgul.ac.uk

Tel: +44 (0) 2087250283

Fax: +44 (0) 2087253487

Words

Abstract: 250 words

Main Text $-3,438$ words

Tables: 2

Figures: 1

\section{Keywords}

mortality; outcomes; coronavirus; COVID-19; SARS-CoV-2 


\section{Abstract \\ Objectives}

Giving appropriate guidance to people living with HIV (PLWH) during the COVID-19 pandemic depends on having adequate data to inform recommendations. Several studies have now been published which inform such advice. The objective of this study was to collate this information and review the implications of emerging data.

\section{Methods}

We performed a systematic literature search of studies relating COVID-19 to HIV infection from the beginning of the pandemic to end of November 2020. We included both published and pre-published manuscripts and analysed papers according to whether they primarily informed risk of infection or risk of adverse outcome.

\section{Results}

68 papers (including 11 pre-prints) were identified. In terms of risk of infection, it appears that PLWH are no more or less likely to become infected with COVID-19. In terms of outcomes and mortality, most early small studies did not demonstrate an increase in mortality compared to background populations. However, several larger, more recent studies from South Africa, New York and two from the UK demonstrate higher mortality among PLWH when results are adjusted for other risk factors, giving relative risks of $2.1,1.2,1.7$ and 2.3 respectively. Apparently conflicting results may arise from differences between studies in their power to account for cofactors and confounding variables. HIV-positive nonsurvivors tend to be younger and have fewer comorbidities than their HIV-negative counterparts; mortality may be higher in PLWH with low CD4 counts.

\section{Conclusions}

Although the literature appears conflicting, large studies which account for covariates strongly suggest that HIV infection increases COVID-19 mortality. 
medRxiv preprint doi: https://doi.org/10.1101/2020.12.04.20240218; this version posted December 7, 2020. The copyright holder for this preprint (which was not certified by peer review) is the author/funder, who has granted medRxiv a license to display the preprint in perpetuity.

It is made available under a CC-BY-NC 4.0 International license .

\section{Introduction.}

The ongoing coronavirus disease-2019 (COVID-19) pandemic, caused by severe acute respiratory syndrome coronavirus-2 (SARS-CoV-2), has emerged as a major global health threat. Two striking features of this disease are, firstly, its often high but variable infectivity and, secondly, the striking range in its clinical consequences. In terms of infectivity, even remote and pre-symptomatic contact may result in infection, (1) whereas highly-exposed household contacts may remain uninfected. Similarly, pathology is highly variable; some infected individuals remain asymptomatic, whereas others develop life-threatening multi-organ failure. Given that the virus is relatively stable, and that this spectrum seems largely independent of the immediate environment, such variability must derive predominantly from host factors. Several host susceptibility factors were recognised early in the pandemic and our understanding of risk factors for serious pathology has evolved rapidly over the last six months. We now recognise that the disease disproportionally affects older people, those with obesity and those with underlying health conditions such as diabetes, renal and cardiovascular disease. (2) This information has allowed the identification of highly-susceptible individuals and driven national and regional guidelines for "shielding" specific groups.

Whether HIV-infected individuals also fall into this "susceptible" group remains a matter for debate. This is a non-trivial issue as some people living with HIV $(\mathrm{PLWH})$ have seen their freedoms curtailed "for their own good", but guidance has varied widely between countries. Are such restrictions necessary or helpful? Early in the pandemic, in the absence of epidemiological evidence, advice followed theoretical reasoning: 'PLWH have impaired immunity so are likely to be more susceptible to COVID-19'. However, in situations where most PLWH are taking antiretroviral treatment (ART) - which we know repletes lymphocyte subsets, restores clinical immunocompetence and endues normal life expectancy - a counter-argument might be made: 'PWLH on effective treatment may be considered no more "susceptible" than the general population'. Some guidelines, distinguished between those on effective treatment and those not; this was the approach taken by BHIVA who advised a more cautious approach for those with CD4 counts $<50$ cells/UI. (3) Basing advice on theoretical considerations is however fraught with 
difficulty in this setting. Firstly, PLWH are very heterogenous; secondly, even those on long-term ART still have a degree of immune dysfunction; thirdly, it might be argued that since most COVID19 pathology is immunopathology, HIV infection may attenuate rather than exaggerate disease severity; finally, some anti-retroviral drugs taken by PLWH may have direct anti-viral effects on SARS-CoV2. Such theoretical complexity underlines the need for good observational data. In the absence of such data, many international guidelines followed a cautious approach in order to protect PLWH from COVID-related morbidity and mortality. $(3,4)$

The object of this paper is to summarise the currently available published or pre-published data on the susceptibility of PLWH to COVID-19. In order to evaluate published data, we utilise a model that separates the two risks that contribute to the probability of having an adverse clinical outcome from COVID-19 (Figure 1). If we denote 'risk of exposure to COVID-19' by $\alpha$, 'risk of becoming infected' by $\beta$, and 'risk of adverse clinical outcome' by $\gamma$, the probability of developing an adverse outcome from COVID-19 infection can be expressed as $\alpha \times \beta \times y$ (Figure 1). Here $\alpha, \beta$ and $y$ are probability coefficients which range between 0 and 1 . Shielding seeks to reduce $\alpha$ and is beyond the scope of this review. We will focus on evidence that informs us whether $\beta$ and/or $y$ are higher for PLWH than for the general population. Firstly, we will consider whether HIV increases susceptibility to SARS-CoV-2 infection; in terms of our model, 'Is $\beta_{\mathrm{HIV}}>\beta_{0}$ ?' (using the suffix to denote the population, HIV being PLWH and 0 being the background population). Secondly, we will ask, does HIV increase the risk of COVID-19 infection developing into severe infection with adverse outcomes? In our model, 'Is $\mathrm{YHIV}_{\mathrm{HIV}} \mathrm{Y}_{0}$ ?' Thirdly, we will ask whether the literature supports risk stratification between PLWH according to CD4 counts and viral load. Such data are important because they provide the evidence base to inform national and regional guidance. 


\section{Methods.}

A review of relevant literature published between December 2019 and a final census date at the end of November 2020 was undertaken. We identified studies using keywords, 'COVID-19', 'coronavirus disease-19', 'SARS-CoV-2', 'novel coronavirus', 'new coronavirus', 'severe acute respiratory syndrome coronavirus 2', 'people living with HIV', 'HIV/ AIDS', 'co-infection', 'immunosuppression' in electronic databases: PubMed, Google Scholar and ScienceDirect, as well as direct searches in specific journals: The Lancet, JAMA, The BMJ, NEJM, Clinical Infectious Diseases, The Journal of Infectious Diseases. Since COVID-19 is a new disease, first identified in December 2019, some recent studies are not yet published. Therefore, the same search terms were used to search for literature on the preprint servers, Medrxiv and Biorxiv. For both published and pre-published studies the selection criteria included primary studies on HIV/ COVID-19 coinfection cases and secondary review studies. For the purposes of this analysis, we present only studies published in English. In total, we identified 68 studies, of which 54 were peer-reviewed, while 11 were preprints and 2 are conference abstracts. 
medRxiv preprint doi: https://doi.org/10.1101/2020.12.04.20240218; this version posted December 7, 2020. The copyright holder for this preprint (which was not certified by peer review) is the author/funder, who has granted medRxiv a license to display the preprint in perpetuity.

It is made available under a CC-BY-NC 4.0 International license .

\section{Results.}

\section{Does HIV increase the susceptibility to SARS-CoV-2 infection?}

In order to answer this question, is $\beta_{\text {HIV }}>\beta_{0}$, we have to rely on the "natural experiment" of pandemic exposure. Since many SARS-CoV-2 infections are asymptomatic, one would ideally compare the prevalence of swab PCR-positivity in PLWH versus the background population regardless of symptoms, assuming similar levels of exposure and assuming a similar magnitude and duration of PCR-positivity (both of which may be untrue). To date, although many community prevalence studies have been performed, to our knowledge, none have yet reported prevalence or incidence of swab-test positivity against HIV status except where prompted by symptoms.

The next-best "natural experiment" is to see if PLWH are over-represented in patients being diagnosed with COVID-19? Of course, this is not completely independent of the severity question (is $\gamma_{H I V}>V_{0}$ ?) since swabbing is usually prompted by the individual accessing healthcare, usually because of symptoms; this will introduce bias if thresholds for testing differ between PLWH and controls. Several studies have reported such data; a summary of HIV/ COVID-19 co-infection studies with prevalence data is shown in Table 1. Most are small and do not specifically focus on the relationship between HIV infection and COVID-19 susceptibility. Richardson et al published a study early in the epidemic that reported the clinical characteristics of 5,700 sequential patients hospitalized with COVID-19. (5) Of these, 43 were HIV seropositive, an HIV prevalence rate of $0.8 \%$, similar to that in the community ( $0.9 \%$ from other sources).(6) More recent studies, conducted mainly in USA and Spain, report similar results. (7-11) These observations tally with our own experience (albeit biased by need for hospitalisation); of 1,584 admissions to our tertiary centre with COVID-19 during the first wave of the pandemic, 11 were seropositive $(0.7 \%)$, a similar proportion to the HIV prevalence of our locality $(0.54 \%)$.

A much larger, more-recent population-based study in New York state captured information on COVID diagnoses from across the state (over 19M people), so should not be biased by need for hospitalisation, but may be influenced by reason for swabbing. (12) Strikingly, although rates of 
medRxiv preprint doi: https://doi.org/10.1101/2020.12.04.20240218; this version posted December 7, 2020. The copyright holder for this preprint (which was not certified by peer review) is the author/funder, who has granted medRxiv a license to display the preprint in perpetuity.

It is made available under a CC-BY-NC 4.0 International license .

COVID diagnosis were higher overall in PLWH (2.8\% versus $1.9 \%)$, when adjusted for other risk factors (age, region of residence, race and ethnicity), the relative risk (RR) was virtually the same as non-HIV infected members of the same community (RR=0.94, 0.91-0.97). (12)

The converse approach is to investigate the incidence of COVID-19 in PLWH versus the general population (rather than the prevalence of HIV in COVID-19 incident cases as above). One Spanish study for example reported 51 co-infections from an HIV clinic population of 2,873 patients. (13) Including all suspected cases, gave a lower incidence rate in PLWH, $1.8 \%$ versus $4.0 \%$ in the community. However, rates were similar when only 'confirmed case' were considered (1.2\% versus $0.9 \%$ ), although confirmatory testing rates differed between PLWH (69\%) and others (22\%). Other studies have taken a similar approach reaching similar conclusions. $(7,14-17)$ Taken together, both prevalence (of HIV) and incidence (of COVID-19) studies seem to point to a rate of infection in PLWH similar to the background population.

\section{Does HIV increase the risk of severe infection with adverse outcomes in COVID-19 infection?}

The second question we sought to address from current literature is whether, once infected, PLWH suffer more adverse outcomes than a comparable population without HIV. In our model this is represented by: 'Is $\mathrm{YH}_{\mathrm{H} I \mathrm{~V}}>\mathrm{Y}_{0}$ '? Detailed clinical outcomes are difficult to define and compare; hence most studies focus on mortality data. A summary of HIV/ COVID-19 co-infection studies with mortality data is shown in Table 2.

The literature broadly splits into two camps. On one hand, there are a large number of small studies, many of which emerged early in the pandemic. Most cite comparisons of crude mortality rates in PLWH versus the background population; generally, they are not powered to control for other comorbidities. However, in the absence of better data, these papers contributed to a general consensus that HIV does not predispose to more severe disease or higher mortality; as one author put it, there is an "... under-representation of people living with HIV (PLWH) among severe 
medRxiv preprint doi: https://doi.org/10.1101/2020.12.04.20240218; this version posted December 7, 2020. The copyright holder for this preprint (which was not certified by peer review) is the author/funder, who has granted medRxiv a license to display the preprint in perpetuity.

It is made available under a CC-BY-NC 4.0 International license .

COVID-19 cases". (18) More recently, four studies have been published with much larger numbers of cases that appear to overturn this relatively benign paradigm, the papers by Boulle et al, (19) Bhaskaran et al, (20) Geretti et al, (21) and Tesoriero et al, (12) which we will consider in more detail.

Boulle et al (19) studied 22,308 public-sector patients with laboratory-confirmed COVID-19 in Western Cape Province, South Africa where the background HIV prevalence is $\sim 7 \%$. Of these 3,978 (18\%) were PLWH. 625 patients died, including 115 PLWH (18\%). Although crude mortality rates are almost identical, age at death was lower in PLWH. Hence, when mortality risk was adjusted for risk factors, including age and gender, it became apparent that, in this cohort, HIV doubled COVID-19 mortality rates (aHR 2.14; 95\% $\mathrm{Cl} 1.70-2.70)$, although the authors acknowledge that the risk might be overestimated due to residual confounding. (Current or past TB also increased COVID-19 mortality.) Interestingly, the effect appeared greater in nonhospitalised patients being "... progressively attenuated when restricting to cases (people with sufficiently severe symptoms to be tested) and hospitalised patients". (19)

Another population-based study reviewed primary care data from $\sim 17 \mathrm{M}$ people in the UK, of whom $0.16 \%$ were HIV-infected (a relatively low proportion as London, where HIV-positivity rates are highest, was under-represented). (20) Of 14,882 people who died from COVID-19-related causes (according to cause of death records) in the first wave of the pandemic, 25 were HIV-positive $(0.17 \%)$. The strength of this study is the wealth of co-morbidity data captured. Adjusting just for age and gender gave a hazard ratio of death of 2.9 for PLWH; when all comorbidities were considered the HR was 2.3. Strikingly, the mortality risk from HIV was greater among people of black ethnicity $(H R=3.8)$. CD4 and viral load data were not available but, in the study setting, 94\% of PLWH would be expected to be on effective ART.

Considering only hospitalised patients, Geretti et al (21) compared 122 HIV/ COVID-19 coinfected patients with 47,470 HIV-negative controls in a large UK-based study (the ISARIC 
medRxiv preprint doi: https://doi.org/10.1101/2020.12.04.20240218; this version posted December 7, 2020. The copyright holder for this preprint (which was not certified by peer review) is the author/funder, who has granted medRxiv a license to display the preprint in perpetuity.

It is made available under a CC-BY-NC 4.0 International license .

WHO CCP study). PLWH were relatively younger with fewer comorbidities than the HIVnegative cohort. Although the crude cumulative 28-day mortality was similar between PLWH and HIV-negative patients ( $26.7 \%$ vs. $32.1 \%, p=0.16$ ), after adjusting for age, PLWH had a $47 \%$ higher mortality rate. After adjusting for further variables (sex, ethnicity, age, baseline date, indeterminate/ probable acquisition of COVID-19, ten comorbidities, hypoxia/receiving oxygen at presentation) HIV was associated with a $69 \%$ higher mortality. The authors could not assess the impact of HIV-related parameters on COVID-19 outcomes as they did not have details of HIV viral load, CD4 count or ART history but they did observe that documented ART was associated with lower mortality.

The Tesoreiro et al study, (12) summarised above also reported mortality risk. Interestingly, in their study, the mortality risk once patients were hospitalised was similar to non-HIV infected individuals, but taking increased diagnosis and admission rates into account, the standardized mortality ratio for PLWH was higher than the general population (1.23; 95\% CI: 1.13-1.48). As in Geretti et al, (21) hospitalized and fatal COVID-19 cases were younger among PLWH.

\section{Do viral load and CD4 status influence COVID-19 risk?}

In many of the studies reviewed, HIV infection is conflated to a single entity. It is clear however that there is a great disparity between someone with suppressed disease (undetectable viral load, high CD4 count) and someone with advanced disease (low CD4 count) and/or an uncontrolled viral load. Many studies have either had insufficient numbers to draw conclusions or been unable to address this issue because of their data collection approach. In terms of data, if we consider CD4 count during the episode as more reflective of COVID-induced lymphopenia than the underlying HIV-related immune deficit, we are left with a relatively small number of studies with CD4 count data preceding the COVID-19 diagnosis. Examples include the Spanish COVID-19 incidence study cited above, (13) which reported a trend linking lower CD4 counts with more severe disease (422 vs 668 cells/uL) but was not significant $(p=0.115)$. In the NYC study, COVID19 diagnosis rates were higher in those with viral suppression (perhaps reflecting greater 
engagement with healthcare) as were PLWH with low CD4 counts. In terms of hospitalisation, those with unsuppressed viral loads and low CD4 counts were more likely to be admitted, but CD4 count was not significantly associated with in-hospital death. (12) In the South African study, those in the $\{\mathrm{VL} \geq 1000$ copies/ml (last 15 months) or CD4 200 cells/ $\mu$ (last 18 months) $\}$ category appeared to have a higher mortality rate, (19) although many patients did not have recent CD4 or viral load measurements, limiting the power of this observation. 
medRxiv preprint doi: https://doi.org/10.1101/2020.12.04.20240218; this version posted December 7, 2020. The copyright holder for this preprint (which was not certified by peer review) is the author/funder, who has granted medRxiv a license to display the preprint in perpetuity.

It is made available under a CC-BY-NC 4.0 International license .

\section{Discussion}

In this paper we summarise the extant literature on the interaction of HIV with COVID-19. We used an analytic model separating risk of infection from risk of severe disease. In terms of risk of infection, the definitive answer would come from asymptomatic screening, but HIV status is unlikely to be collected as part of such exercises. Hence, diagnosis rates are the next-best surrogate marker, even though they are profoundly influenced by the occurrence of symptoms or hospitalization. We identified 27 studies to date which address infection risk as a function of HIV status. Most studies assessed HIV prevalence in COVID-19 diagnosed individuals, although some followed COVID-19 incidence in HIV clinic cohorts. $(7,13-17)$ The consensus that has emerged provides reassurance that PLWH appear no more likely to become infected than their non-infected counterparts; in our model, $\beta_{\text {HIV }} \approx \beta_{0}$. The caveat to this conclusion is that PLWH may have been shielding or otherwise reducing their exposure (reducing the factor, $\alpha$ ) during the pandemic, in which case, true infection risk may be higher than estimated.

In terms of severity, early studies were reassuring. PLWH did not appear over-represented among those experiencing complications with COVID-19. However, it is now apparent that, when adjusted for other risk factors, even well-controlled HIV infection does appear associated with increased mortality risk. Indeed, much of the disparity between the findings of different studies can be accounted for by the way in which authors have accounted (or not) for co-factors and confounders in their models. Almost all studies that have considered comorbidities have found that the same factors operate within HIV-positive COVID-19-infected cohorts as have been identified in the general population (age, cardiovascular disease, obesity etc), as might be expected. Taking cofactors into account is not possible in small studies, but larger studies allow adjustment which may be crucial for interpretation. So, for example, in Geretti et al (21) and Bhaskaran et al, (20) unadjusted mortality rates in PLWH are no higher than background mortality rates. However, in both studies, once data are adjusted for age etc, the independent adverse impact of HIV infection is evident. This increased mortality risk with HIV infection manifests itself in different parts of the patient pathway in different settings. Thus in the South African study cited above, the increased 
medRxiv preprint doi: https://doi.org/10.1101/2020.12.04.20240218; this version posted December 7, 2020. The copyright holder for this preprint (which was not certified by peer review) is the author/funder, who has granted medRxiv a license to display the preprint in perpetuity.

It is made available under a CC-BY-NC 4.0 International license .

mortality risk was most apparent in non-hospitalised individuals; (19) in the NYC study, the big difference was in diagnosis and hospitalisation rates - once admitted mortality was similar to nonHIV-infected individuals; (12) in the UK study, in which hospitalisation was an entry criterion, mortality rates were found to be significantly higher in PLWH after admission. (21)

It does therefore appear reasonable to take HIV status into account in developing policies and practice, but do we treat all PLWH the same? What about the impact of CD4 count and viral load? Here, the data is far less clear-cut. We can postulate with some confidence that the additional risk of HIV infection for mortality seems to apply even to those with well-controlled HIV. Several studies observe an independent effect of HIV infection across all strata; for example Tesoriero et al found an increased hospitalisation risk in individuals with CD4 $\geq 500$ and viral suppression. (12) Furthermore, the two UK studies discussed above were performed in settings where $94 \%$ of subjects would be expected to be well-controlled. Whether those with low CD4 counts and/or viraemia are at higher risk remains unclear. Several studies show a relationship between lower CD4 counts and worse outcomes, $(12-13,19)$, but some studies suggest low CD4 counts are protective. $(7,22)$ Although it might appear counter-intuitive that "immunosuppression" would worsen "immunopathology", it should be remembered that advanced HIV is characterised by immune dysfunction with heightened levels of immune activation as much as "immunosuppression".

Recommendations based upon CD4 and/or viral load status thus appear to have a weak evidencebase, but may be justified in a pragmatic risk-stratified model. Current UK guidelines differentiate those with a CD4 count $<50$ cells/uL for special consideration, (3) but there is little evidence supporting where to make this cut-off. In the NYC study, the authors separated out a cohort with a CD4 count $<200$ cells/uL or $<14 \%$ ("Stage 3") and found they had a higher HIV-attributable mortality risk, (12) but they did not explore lower cut-offs. At the other end of the scale, it does not appear possible to define a "safe" level of CD4 count from the studies published to date; indeed, one can argue from the mortality impact of HIV even in settings where almost everyone is on 
medRxiv preprint doi: https://doi.org/10.1101/2020.12.04.20240218; this version posted December 7, 2020. The copyright holder for this preprint (which was not certified by peer review) is the author/funder, who has granted medRxiv a license to display the preprint in perpetuity. It is made available under a CC-BY-NC 4.0 International license .

effective treatment, (20-21) that no such "safe" level exists. One might however pragmatically define a level where recommendations for PLWH match those for the general population. Such stratified advice is likely to vary on a regional basis. Currently, the countries with most COVID-19 cases are relatively low HIV seroprevalence countries. Conversely, countries with high HIV seroprevalence may have limited COVID-19 testing resources and incidence rates may be underestimated. This is why studies such as Boulle et al (19) are particularly valuable as they address COVID-19 risks in a high HIV burden setting (as well as making intriguing observations about TB/COVID interactions). Although their conclusions may not be generalisable to other settings, the consistency in message, if not magnitude, of the effect of HIV on COVID-19 mortality across all the larger studies cited is notable.

This overview has attempted to be comprehensive, but we may have missed publications and have not captured those in languages other than English. Of course, in such a rapidly-changing situation new studies are being published every month but this study summarises the current state-of-play and constitutes a comprehensive basis for future literature reviews. We have deliberately chosen not to focus on whether some antiretroviral drugs impact COVID-19 outcomes directly as the data are conflicting and such questions are best addressed in prospective clinical trials. We considered a meta-analysis, but after reviewing the disparate nature of studies with their different data collection strategies, and estimating the number of studies that would need to be excluded, felt that a comprehensive descriptive analysis was more helpful.

Understanding the impact of HIV on COVID-19 is important in order to inform guidance and policy. "Shielding" has costs in terms of emotional and psychological wellbeing, finances and quality of life. If PLWH are to be asked to take extra precautions, this guidance needs to be based on good data. Additionally, as vaccines become available, prioritisation for vaccination is likely, in which case we need data to establish where PLWH stand in any risk-stratification. Despite an extensive body of literature, more research is needed to clarify risk in different settings and particularly to clarify how guidance should be shaped by measures such as CD4 count and viral load, but the 
medRxiv preprint doi: https://doi.org/10.1101/2020.12.04.20240218; this version posted December 7, 2020. The copyright holder for this preprint (which was not certified by peer review) is the author/funder, who has granted medRxiv a license to display the preprint in perpetuity. It is made available under a CC-BY-NC 4.0 International license.

new data from large studies is consistent: even well-controlled HIV appears associated with an increased COVID-19 mortality risk.

\section{Acknowledgements}

We acknowledge the help of Rebecca Marchant, Lisa Hamzah and Padmini Parthasarathi in evaluating local rates of COVID-19 among PLWH. 


\section{Tables}

\section{Table 1. HIV/ COVID-19 co-infection studies with prevalence data}

\begin{tabular}{|c|c|c|c|c|c|}
\hline \# & Authors & Setting & $\begin{array}{l}\text { Number of } \\
\text { participants }\end{array}$ & Readout & Comments / Conclusions \\
\hline 1 & Tesoriero et al (12) & $\begin{array}{l}\text { New York } \\
\text { State, USA }\end{array}$ & $\begin{array}{l}2,988 \text { HIV/ COVID-19, vs } 375,260 \\
\text { non-HIV COVID-19 from a population } \\
\text { of } 19.4 \mathrm{M}\end{array}$ & $\begin{array}{l}\text { 1.43-fold higher risk of COVID-19 in } \\
\text { PLWH vs non-HIV, but difference } \\
\text { disappears with adjustment for other } \\
\text { factors. }\end{array}$ & $\begin{array}{l}\text { PLWH have a similar adjusted risk of } \\
\text { infection as non-HIV individuals } \\
(\mathrm{RR}=0.94,0.91-0.97)\end{array}$ \\
\hline 2 & Toombs et al (23) & UK & $\begin{array}{l}3 \text { HIV/ COVID-19 from a population } \\
\text { of } 500,000\end{array}$ & $\begin{array}{l}\text { HIV prevalence in the catchment area } \\
\text { and COVID-19 patients }(0.34 \% \text { vs } \\
0.43 \%)\end{array}$ & $\begin{array}{l}\text { HIV does not appear to increase the } \\
\text { risk of contracting COVID-19 }\end{array}$ \\
\hline 3 & $\begin{array}{l}\text { Molina-Iturritza et al } \\
\text { (7) }\end{array}$ & $\begin{array}{l}\text { Basque } \\
\text { Country, } \\
\text { Spain }\end{array}$ & $\begin{array}{l}8 \mathrm{HIV} / \mathrm{COVID}-19 \text { out of } 902 \mathrm{PLWH} \\
\text { from a population of } 331,549\end{array}$ & $\begin{array}{l}\text { Similar prevalence to the general } \\
\text { population, } 0.89 \% \text { vs } 0.93 \%\end{array}$ & $\begin{array}{l}\text { HIV does not appear to increase the } \\
\text { risk of contracting COVID-19 }\end{array}$ \\
\hline 4 & Sachdev et al (8) & $\begin{array}{l}\text { San } \\
\text { Francisco, } \\
\text { USA }\end{array}$ & $\begin{array}{l}193 \text { HIV/ COVID-19 vs } 9,626 \text { non- } \\
\text { HIV COVID-19 from a population of } \\
276,807\end{array}$ & $\begin{array}{l}\text { Similar prevalence to HIV-negative } \\
\text { people tested for COVID-19, } 4.5 \% \text { vs } \\
3.5 \%\end{array}$ & $\begin{array}{l}\text { "In San Francisco, susceptibility to } \\
\text { COVID-19 was increased among } \\
\text { PLWH over the first } 6 \text { months of the } \\
\text { pandemic" }\end{array}$ \\
\hline 5 & Braunstein et al (9) & NYC & $\begin{array}{l}2,410 \text { HIV/ COVID-19 out of } 204,583 \\
\text { COVID-19 and } 113,907 \text { PLWH } \\
\text { without COVID-19 }\end{array}$ & $\begin{array}{l}\text { Similar prevalence to the general } \\
\text { population, } 1.2 \% \text { vs } 1.5 \%\end{array}$ & $\begin{array}{l}\text { HIV does not appear to increase the } \\
\text { risk of contracting COVID-19 }\end{array}$ \\
\hline 6 & Park et al (24) & USA & $\begin{array}{l}189 \mathrm{HIV} / \mathrm{COVID}-19 \text { and } 380 \mathrm{HIV}- \\
\text { negative COVID-19 from a population } \\
\text { of } 107,636\end{array}$ & $\begin{array}{l}\text { Similar prevalence between the } 2 \\
\text { groups, } 12.7 \% \text { vs } 13.9 \% \text { of whom } \\
\text { tested for COVID-19 }\end{array}$ & $\begin{array}{l}\text { HIV does not appear to increase the } \\
\text { risk of contracting COVID-19 }\end{array}$ \\
\hline 7 & Del Amo et al (14) & Spain & $\begin{array}{l}\text { 77,590 PLWH of whom } 236 \mathrm{HIV/} \\
\text { COVID-19 }\end{array}$ & $\begin{array}{l}\text { Risk of incidence }(30.0 \text { per } 10000) \\
\text { lower than the general population } \\
(41.7 \text { per } 10000)\end{array}$ & $\begin{array}{l}\text { Risk of COVID-19 diagnosis lower } \\
\text { among PLWH receiving TDF/FTC } \\
\text { than other ART }\end{array}$ \\
\hline 8 & Cabello et al (10) & $\begin{array}{l}\text { Madrid, } \\
\text { Spain }\end{array}$ & $\begin{array}{l}66,860 \mathrm{COVID}-19 \text { pts, of whom } 63 \\
\text { were } \mathrm{HIV+}\end{array}$ & $\begin{array}{l}\text { Similar prevalence rate to the } \\
\text { community, } 0.86 \% \text { (confirmed cases) } \\
-1.68 \% \text { (confirmed + suspected) vs }\end{array}$ & $\begin{array}{l}\text { HIV severity or type of ART do not } \\
\text { influence COVID-19 outcome }\end{array}$ \\
\hline
\end{tabular}




\begin{tabular}{|c|c|c|c|c|c|}
\hline & & & & $\begin{array}{l}1 \% \text { (confirmed cases in the } \\
\text { community) }\end{array}$ & \\
\hline 9 & Gudipati et al (25) & $\begin{array}{l}\text { Detroit, } \\
\text { Michigan, } \\
\text { USA }\end{array}$ & $\begin{array}{l}14 \text { HIV/ COVID-19 out of } 7,372 \\
\text { COVID- } 19 \text { pts at the local clinic from } \\
\text { a population of } 65,549 \text { COVID-19 } \\
(278 \text { HIV/ COVID-19) }\end{array}$ & $\begin{array}{l}\text { Similar incidence to the general } \\
\text { population, } 1.6 \% \text { vs } 1.7 \%\end{array}$ & $\begin{array}{l}\text { HIV does not appear to increase the } \\
\text { risk of contracting COVID-19 }\end{array}$ \\
\hline 10 & Marcello et al (11) & NYC, USA & $\begin{array}{l}159 \mathrm{HIV} / \mathrm{COVID}-19 \text { out of } 13,442 \\
\text { COVID-19 from a population of } \\
22,176 \text { ( } 277 \mathrm{PLWH})\end{array}$ & $\begin{array}{l}\text { Similar prevalence to the community } \\
1.18 \% \text { vs } 1.24 \%\end{array}$ & $\begin{array}{l}\text { No significant association between } \\
\text { HIV and hospitalization }\end{array}$ \\
\hline 11 & Charre et al (26) & $\begin{array}{l}\text { Rhone, Lyon, } \\
\text { France }\end{array}$ & $\begin{array}{l}12 \text { HIV/ COVID-19; } 4 \text { PrEP user/ } \\
\text { COVID-19 and 3,632 HIV-negative } \\
\text { COVID-19 from a tested population of } \\
19113\end{array}$ & $\begin{array}{l}\text { Similar prevalence between PLWH, } \\
\text { PrEP users and HIV-negative cohort, } \\
15.6 \% \text { vs } 14.8 \% \text { vs } 19.1 \%\end{array}$ & $\begin{array}{l}\text { Similar risk of symptomatic COVID- } \\
19 \text { to the general population }\end{array}$ \\
\hline 12 & $\begin{array}{l}\text { Miyashita and Kuno } \\
(27)\end{array}$ & NYC, USA & 8,912 COVID-19 of whom 161 PLWH & $\begin{array}{l}\text { Similar HIV prevalence to community } \\
1.8 \% \text { vs } 1.3 \%\end{array}$ & $\begin{array}{l}\text { HIV does not appear to increase the } \\
\text { risk of contracting COVID-19 }\end{array}$ \\
\hline 13 & Huang et al (15) & $\begin{array}{l}\text { Wuhan, } \\
\text { China }\end{array}$ & $\begin{array}{l}6001 \mathrm{PLWH} \text { of whom } 35 \mathrm{HIV} / \\
\text { COVID-19 }\end{array}$ & $\begin{array}{l}\text { Similar incidence to the general } \\
\text { population, } 0.58 \% \text { vs } 0.46 \%\end{array}$ & $\begin{array}{l}\text { Older age }(>50) \text { and ART } \\
\text { discontinuation sharply increases } \\
\text { COVID-19 incidence among PLWH }\end{array}$ \\
\hline 14 & Richardson et al (5) & NYC, USA & $\begin{array}{l}\text { 5,700 COVID-19 of whom } 43 \text { HIV/ } \\
\text { COVID-19 }\end{array}$ & $\begin{array}{l}0.8 \% \text { HIV prevalence in hospitalised } \\
\text { patients with COVID-19 versus } 0.9 \% \\
\text { in community }\end{array}$ & $\begin{array}{l}\text { Sequential hospitalised patients. No } \\
\text { clinical details for HIV+ presented. }\end{array}$ \\
\hline 15 & Inciarte et al (16) & $\begin{array}{l}\text { Barcelona, } \\
\text { Spain }\end{array}$ & $\begin{array}{l}\text { 5,683 PLWH of whom } 53 \text { HIV/ } \\
\text { COVID-19 }\end{array}$ & $\begin{array}{l}\text { Lower incidence }(62 \%) \text { than the } \\
\text { population in Barcelona }\end{array}$ & $\begin{array}{l}\text { Lower standardized incidence rate } \\
\text { than the general population }\end{array}$ \\
\hline 16 & D'Souza et al (28) & USA & $\begin{array}{l}2,078 \text { PLWH out of } 3,411 \text { survey } \\
\text { participants }\end{array}$ & $\begin{array}{l}\text { Among participants tested for } \\
\text { COVID-19 PLWH had higher positive } \\
\text { results, }(11.2 \% \text { vs } 6.1 \%, p=0.08)\end{array}$ & $\begin{array}{l}\text { "SARS-CoV-2 infection may be } \\
\text { elevated among PLWH" }\end{array}$ \\
\hline 17 & Vizcarra $\mathrm{P}$ et al (13) & $\begin{array}{l}\text { Madrid, } \\
\text { Spain }\end{array}$ & $\begin{array}{l}51 \text { HIV/ COVID-19 vs } 1,288 \text { non- } \\
\text { COVID-19 HIV pts from 2,873 PLWH }\end{array}$ & $\begin{array}{l}\text { Slightly higher prevalence than the } \\
\text { general population: } 1.2 \% \text { vs } 0.96 \%\end{array}$ & $\begin{array}{l}\text { Higher prevalence for confirmed } \\
\text { cases, lower prevalence after } \\
\text { including suspected cases: } 1.8 \% \text { vs } \\
4.0 \% \text {. }\end{array}$ \\
\hline 18 & Shalev et al (29) & NYC, USA & $\begin{array}{l}2,159 \text { COVID-19 of whom } 31 \text { HIV/ } \\
\text { COVID-19 }\end{array}$ & $\begin{array}{l}\text { HIV prevalence in the catchment area } \\
\text { and COVID-19 patients }(1.4 \% \text { vs } \\
1.5 \%)\end{array}$ & $\begin{array}{l}\text { HIV does not increase the risk of } \\
\text { contracting COVID-19 }\end{array}$ \\
\hline
\end{tabular}




\begin{tabular}{|c|c|c|c|c|c|}
\hline 19 & Jimenez et al (30) & $\begin{array}{l}\text { Madrid, } \\
\text { Spain }\end{array}$ & $\begin{array}{l}9 \text { HIV/ COVID- } 19 \text { out of } 1,542 \\
\text { COVID- } 19\end{array}$ & Low HIV prevalence (0.6\%) & No clinical details for HIV+ presented. \\
\hline 20 & Mondi et al (31) & Rome, Italy & $\begin{array}{l}604 \text { COVID-19 of whom } 5 \text { HIV/ } \\
\text { COVID-19 }\end{array}$ & $\begin{array}{l}\text { PLWH represent less than } 1 \% \text { of all } \\
\text { COVID- } 19 \text { cases admitted to the } \\
\text { hospital; Not compared to the general } \\
\text { population }\end{array}$ & $\begin{array}{l}\text { PLWH do not appear at increased } \\
\text { risk of contracting COVID-19 }\end{array}$ \\
\hline 21 & Blanco et al (32) & Spain & $\begin{array}{l}543 \text { COVID-19 of whom } 5 \text { HIV/ } \\
\text { COVID-19 }\end{array}$ & $\begin{array}{l}1 \% \text { HIV prevalence in patients with } \\
\text { COVID- } 19\end{array}$ & $\begin{array}{l}4 \text { discharged, } 1 \text { in ICU; Community } \\
\text { prevalence not cited }\end{array}$ \\
\hline 22 & Goyal et al (33) & NYC, USA & $\begin{array}{l}393 \text { COVID-19 of whom } 7 \text { HIV/ } \\
\text { COVID-19 }\end{array}$ & $\begin{array}{l}\text { 1.8\% HIV prevalence in patients with } \\
\text { COVID-19 }\end{array}$ & Clinical details not presented \\
\hline 23 & Sasset et al (34) & Padua, Italy & $\begin{array}{l}2 \text { HIV/ COVID-19 ( } 1,745 \text { PLWH in the } \\
\text { community) out of } 383 \text { hospitalized } \\
\text { COVID-19 }\end{array}$ & 1 discharged, 1 in ICU & $\begin{array}{l}\text { Low prevalence }(0.5 \%) \text { of PLWH } \\
\text { among hospitalized patients }\end{array}$ \\
\hline 24 & $\begin{array}{l}\text { Fernandez-Fuertes } \\
\text { et al (17) }\end{array}$ & $\begin{array}{l}\text { Southern } \\
\text { Spain }\end{array}$ & $4 \mathrm{HIV} / \mathrm{COVID}-19$ out of $326 \mathrm{PLWH}$ & $\begin{array}{l}\text { Similar incidence to the general } \\
\text { population, } 1.22 \% \text { vs } 0.417 \%\end{array}$ & $\begin{array}{l}\text { HIV does not appear to increase the } \\
\text { risk of contracting COVID-19 }\end{array}$ \\
\hline 25 & Karim et al (35) & $\begin{array}{l}\text { KwaZulu- } \\
\text { Natal, South } \\
\text { Africa }\end{array}$ & $\begin{array}{l}55 \mathrm{HIV} / \mathrm{COVID}-19 \text { out of } 124 \text { COVID- } \\
19\end{array}$ & $\begin{array}{l}\text { Higher prevalence than the general } \\
\text { population, } 44 \% \text { vs } 18 \%\end{array}$ & $\begin{array}{l}\text { HIV does not appear to increase the } \\
\text { risk of contracting COVID-19 } \\
\text { (considering age and gender } \\
\text { distribution of participants) }\end{array}$ \\
\hline 26 & Parker et al (36) & $\begin{array}{l}\text { Cape Town, } \\
\text { South Africa }\end{array}$ & $\begin{array}{l}24 \text { HIV/ COVID- } 19 \text { out of } 116 \text { COVID- } \\
19 \text { pts }\end{array}$ & $\begin{array}{l}\text { Higher prevalence than the general } \\
\text { population, } 21 \% \text { vs } 12.6 \%\end{array}$ & $\begin{array}{l}\text { "PLWH may have a high probability } \\
\text { of hospital admission..." }\end{array}$ \\
\hline 27 & Härter et al (37) & Germany & $32 \mathrm{HIV} / \mathrm{COVID}-19$ & $\begin{array}{l}\text { Higher hospitalization than the } \\
\text { general population ( } 42 \% \text { vs } 17 \%)\end{array}$ & $\begin{array}{l}\text { Measured only symptomatic } \\
\text { hospitalization rate }\end{array}$ \\
\hline
\end{tabular}

*Studies ranked by number of participants. Note studies may also appear in Table 2. All papers are 2020 publication date. Abbreviations: PrEP, preexposure prophylaxis (HIV); NYC, New York City; ICU, Intensive Care Unit. Studies \# 1; 4; 10; 24; 25 are pre-published at the time of writing. 
Table 2. HIV/ COVID-19 co-infection studies with mortality data

\begin{tabular}{|c|c|c|c|c|c|}
\hline$\#$ & Authors & Setting & $\begin{array}{l}\text { Number of } \\
\text { participants }\end{array}$ & Readout & Conclusion \\
\hline 1 & $\begin{array}{l}\text { Tesoriero et al } \\
(12)\end{array}$ & $\begin{array}{l}\text { New York } \\
\text { State, USA }\end{array}$ & $\begin{array}{l}2,988 \text { HIV/ COVID-19, vs } 375,260 \\
\text { non-HIV COVID-19 from a population } \\
\text { of } 19.4 \mathrm{M}\end{array}$ & $\begin{array}{l}2.55 \text {-fold higher mortality than the } \\
\text { general population }\end{array}$ & $\begin{array}{l}\text { PLWH had poorer COVID-19 } \\
\text { outcomes than HIV-negative people }\end{array}$ \\
\hline 2 & $\begin{array}{l}\text { Bhaskaran et al } \\
(20)\end{array}$ & UK & $\begin{array}{l}27,480 \mathrm{HIV} / \mathrm{COVID}-19 \text { from a } \\
\text { population of } 17.3 \mathrm{M}\end{array}$ & $\begin{array}{l}25 \text { died; PLWH had 2.3-fold higher } \\
\text { mortality risk after adjusting for age, } \\
\text { gender, ethnicity, deprivation and } \\
\text { comorbidities }\end{array}$ & $\begin{array}{l}\text { "PLWH may be a high-risk group for } \\
\text { COVID-19 death" }\end{array}$ \\
\hline 3 & Boulle et al (19) & South Africa & $\begin{array}{l}22,308 \text { COVID- } 19 \text { pts, (from } \\
\text { population number of } 3.5 \mathrm{M} \text { ) of whom } \\
3,978 \text { HIV+ }\end{array}$ & $\begin{array}{l}\text { HIV associated with higher risk of } \\
\text { death: aHR } 2.14(1.70-2.70)\end{array}$ & $\begin{array}{l}\text { PLWH should be considered more } \\
\text { susceptible to COVID-19 mortality }\end{array}$ \\
\hline 4 & Byrd et al (38) & RI, USA & $\begin{array}{l}27 \text { HIV/ COVID-19 from a population } \\
\text { of } 1.06 \mathrm{M}(2800 \text { PLWH) }\end{array}$ & 1 died & $\begin{array}{l}\text { Similar clinical outcomes to the } \\
\text { general population }\end{array}$ \\
\hline 5 & Toombs et al (23) & UK & $\begin{array}{l}3 \mathrm{HIV} / \mathrm{COVID}-19 \text { from a population } \\
\text { of } 500000\end{array}$ & 1 died; 2 were discharged & $\begin{array}{l}\text { HIV does not increase the risk of } \\
\text { mortality from COVID-19- but only } \\
n=3\end{array}$ \\
\hline 6 & $\begin{array}{l}\text { Molina-Iturritza et } \\
\text { al (7) }\end{array}$ & $\begin{array}{l}\text { Basque } \\
\text { Country, } \\
\text { Spain }\end{array}$ & $\begin{array}{l}8 \mathrm{HIV} / \mathrm{COVID}-19 \text { out of } 902 \mathrm{PLWH} \\
\text { from a population of } 331,549\end{array}$ & 1 died & $\begin{array}{l}3 \text { patients with the worst clinical } \\
\text { course had a CD } 4>400 \text { cells } / \mu l\end{array}$ \\
\hline 7 & Sachdev et al (8) & $\begin{array}{l}\text { San } \\
\text { Francisco, } \\
\text { USA }\end{array}$ & $\begin{array}{l}193 \text { HIV/ COVID-19 vs } 9,626 \text { non- } \\
\text { HIV COVID-19 from a population of } \\
276,807\end{array}$ & & $\begin{array}{l}\text { Risk of severe COVID-19 was not } \\
\text { increased among PLWH }\end{array}$ \\
\hline 8 & $\begin{array}{l}\text { Braunstein et al } \\
\text { (9) }\end{array}$ & NYC & $\begin{array}{l}2,410 \text { HIV/ COVID-19 out of } 204,583 \\
\text { COVID-19 and } 113,907 \text { PLWH } \\
\text { without COVID-19 }\end{array}$ & 312 died & $\begin{array}{l}\text { Higher mortality rate than the general } \\
\text { population, } 13 \% \text { vs } 8 \%\end{array}$ \\
\hline
\end{tabular}




\begin{tabular}{|c|c|c|c|c|c|}
\hline 9 & Park LS (24) & USA & $\begin{array}{l}189 \mathrm{HIV} / \mathrm{COVID}-19 \text { and } 380 \mathrm{HIV}- \\
\text { negative COVID-19 from a population } \\
\text { of } 107,636\end{array}$ & $\begin{array}{l}\text { Risk of severe COVID-19 was similar } \\
\text { between the } 2 \text { groups }\end{array}$ & $\begin{array}{l}\text { HIV was not associated with severe } \\
\text { COVID-19 }\end{array}$ \\
\hline 10 & Del Amo et al (14) & Spain & $\begin{array}{l}\text { 77,590 PLWH of whom } 236 \mathrm{HIV/} \\
\text { COVID-19 }\end{array}$ & 20 died & $\begin{array}{l}\text { Higher risk of mortality than the } \\
\text { general population } 3.7 \text { per } 10,000 \text { vs } \\
2.1 \text { per } 10,000\end{array}$ \\
\hline 11 & Cabello et al (10) & $\begin{array}{l}\text { Madrid, } \\
\text { Spain }\end{array}$ & $\begin{array}{l}66,860 \text { COVID-19 pts, of whom } 63 \\
\text { were HIV+ }\end{array}$ & $\begin{array}{l}\text { Lower mortality rate than the } \\
\text { community, } 3.2 \% \text { vs } 13.3 \%\end{array}$ & $\begin{array}{l}\text { HIV severity or type of ART do not } \\
\text { influence COVID- } 19 \text { outcome }\end{array}$ \\
\hline 12 & Gudipati et al (25) & $\begin{array}{l}\text { Michigan, } \\
\text { USA }\end{array}$ & $\begin{array}{l}14 \text { HIV/ COVID-19 out of } 7372 \\
\text { COVID-19 pts at the local clinic from } \\
\text { a population of } 65,549 \text { COVID-19 } \\
(278 \text { HIV/ COVID-19) }\end{array}$ & $\begin{array}{l}3 \text { died }(21 \%) ; \text { mortality rate in } \\
\text { community } 9 \%\end{array}$ & $\begin{array}{l}\text { PLWH are not at higher risk of severe } \\
\text { COVID-19 }\end{array}$ \\
\hline 13 & Etienne et al (39) & Paris, France & $\begin{array}{l}54 \text { HIV/ COVID-19 from a population } \\
\text { of } 51,000 \text { PLWH }\end{array}$ & 1 died & $\begin{array}{l}\text { Not compared to the general } \\
\text { population }\end{array}$ \\
\hline 14 & Hadi et al (40) & $\begin{array}{l}\text { Massachuset } \\
\text { ts, USA }\end{array}$ & $\begin{array}{l}404 \text { HIV/ COVID-19 and } 49763 \text { HIV- } \\
\text { negative pts ( } 404 \text { propensity- } \\
\text { matched) }\end{array}$ & $\begin{array}{l}\text { Crude mortality higher in PLWH; no } \\
\text { difference in propensity-matched } \\
\text { analysis }\end{array}$ & $\begin{array}{l}\text { PLWH are at higher risk of adverse } \\
\text { outcomes from COVID-19 (due to } \\
\text { higher burden of comorbidities) }\end{array}$ \\
\hline 15 & Geretti et al (21) & UK & $\begin{array}{l}122 \mathrm{HIV} / \mathrm{COVID}-19 \text { and } 47,470 \mathrm{HIV}- \\
\text { negative controls }\end{array}$ & $\begin{array}{l}\text { After adjusting for age } 47 \% \text { higher } \\
\text { risk of mortality than HIV-negative } \\
\text { cohort }\end{array}$ & $\begin{array}{l}\text { HIV may be associated with higher } \\
\text { mortality rate from COVID-19 }\end{array}$ \\
\hline 16 & Wang et al (41) & NYC & $\begin{array}{l}52 \text { HIV/ COVID-19 out of } 3,273 \\
\text { hospitalized COVID-19 (from } 28,336 \\
\text { patients tested for COVID-19) }\end{array}$ & 10 died & \\
\hline 17 & Marcello et al (11) & NYC & $\begin{array}{l}159 \text { HIV/ COVID-19 out of } 13,442 \\
\text { COVID-19 from a population of } \\
22,176(277 \text { PLWH) }\end{array}$ & 20 died & $\begin{array}{l}\text { No significant association between } \\
\text { HIV and hospitalization }\end{array}$ \\
\hline 18 & Di Biagio et al (42) & Italy & $\begin{array}{l}69 \text { HIV/ COVID-19 (38 hospitalised) } \\
\text { out of } 22,000 \text { COVID-19 cases }\end{array}$ & $\begin{array}{l}\text { Mortality rate in PLWH: } 1 \text { out of non- } \\
\text { hospitalised and } 6 \text { out of hospitalised } \\
\text { PLWH }\end{array}$ & $\begin{array}{l}\text { Could not be compared to mortality } \\
\text { rates in the general population; low } \\
\text { CD4 can be associated with severe } \\
\text { COVID-19 }\end{array}$ \\
\hline 19 & Hassan et al (43) & Nigeria & $\begin{array}{l}15,742 \text { (303 deaths) COVID-19 in } \\
\text { high burden states and 9,952 ( } 287 \\
\text { deaths) COVID-19 in other } 30 \text { states }\end{array}$ & $\begin{array}{l}\text { HIV prevalence } 3.7 \text { in high burden; } \\
2.9 \text { in other } 30 \text { states }\end{array}$ & $\begin{array}{l}\text { Mortality rate was lower in states with } \\
\text { higher HIV prevalence; "HIV } \\
\text { prevalence had a protective effect" }\end{array}$ \\
\hline
\end{tabular}




\begin{tabular}{|c|c|c|c|c|c|}
\hline 20 & Bastos et al (44) & $\begin{array}{l}\text { Lisbon, } \\
\text { Portugal }\end{array}$ & $\begin{array}{l}14 \text { HIV/ COVID-19 (132 PLWH } \\
\text { tested) out of } 815 \text { COVID-19 }(12,192 \\
\text { HIV-negative tested) }\end{array}$ & All survived & $\begin{array}{l}\text { "Evolution of COVID-19 was similar } \\
\text { between PLWH and non-HIV } \\
\text { patients" }\end{array}$ \\
\hline 21 & $\begin{array}{l}\text { Miyashita and } \\
\text { Kuno (27) }\end{array}$ & NYC & 8,912 COVID-19 of whom $161 \mathrm{PLWH}$ & $\begin{array}{l}\text { Death rate: } 23 \text { (14\%) in PLWH and } \\
1,235(14 \%) \text { in HIV-negative cohort }\end{array}$ & $\begin{array}{l}\text { Higher mortality rate in PLWH } \\
\text { younger than } 50 \text { years; no significant } \\
\text { difference in other age groups }\end{array}$ \\
\hline 22 & Huang et al (15) & $\begin{array}{l}\text { Wuhan, } \\
\text { China }\end{array}$ & $\begin{array}{l}6001 \mathrm{PLWH} \text { of whom } 35 \mathrm{HIV} / \\
\text { COVID-19 }\end{array}$ & $\begin{array}{l}\text { Similar mortality rate to the general } \\
\text { population, } 5.7 \% \text { vs } 7.7 \%\end{array}$ & $\begin{array}{l}\text { Delayed viral clearance, HIV-related } \\
\text { immunosuppression might result in } \\
\text { SARS-CoV-2 persistence }\end{array}$ \\
\hline 23 & $\begin{array}{l}\text { Gervasoni et al } \\
(45)\end{array}$ & Milan, Italy & $47 \mathrm{HIV} / \mathrm{COVID}-19$ out of $6000 \mathrm{PLWH}$ & $\begin{array}{l}\text { Lower mortality rates than HIV- } \\
\text { negative cohort ( } 4 \% \text { vs } 17 \%)\end{array}$ & $\begin{array}{l}\text { Numbers small: } 2 \text { died; one } \\
\text { overweight, one with comorbidities }\end{array}$ \\
\hline 24 & Inciarte et al (16) & $\begin{array}{l}\text { Barcelona, } \\
\text { Spain }\end{array}$ & $\begin{array}{l}\text { 5,683 PLWH of whom } 53 \text { HIV/ } \\
\text { COVID-19 }\end{array}$ & 2 died & $\begin{array}{l}\text { HIV was not associated with severe } \\
\text { COVID-19 }\end{array}$ \\
\hline 25 & Isernia et al (46) & Paris, France & $30 \mathrm{HIV} / \mathrm{COVID}-19$ out of $5327 \mathrm{PLWH}$ & $\begin{array}{l}\text { Not compared to the general } \\
\text { population }\end{array}$ & $\begin{array}{l}2 \text { died; HIV is probably not an } \\
\text { independent risk factor for COVID-19 }\end{array}$ \\
\hline 26 & Patel et al (47) & $\begin{array}{l}\text { Bronx, NY, } \\
\text { USA }\end{array}$ & $\begin{array}{l}4,662 \text { COVID-19 pts, of whom } 77 \\
\text { HIV+ }\end{array}$ & $\begin{array}{l}14(18 \%) \text { PLWH died compared to } \\
1037(23 \%) \text { HIV-negative pts }\end{array}$ & $\begin{array}{l}\text { No significant difference in mortality } \\
\text { between PLWH and HIV-negative } \\
\text { cohort }\end{array}$ \\
\hline 27 & Sigel et al (48) & NYC & $\begin{array}{l}88 \mathrm{HIV} / \mathrm{COVID}-19 \text { and } 405 \mathrm{HIV}- \\
\text { negative matched controls from } 4,402 \\
\text { COVID-19 pts }\end{array}$ & $\begin{array}{l}\text { Similar disease course and mortality } \\
\text { rates to HIV-negative controls }\end{array}$ & $\begin{array}{l}\text { No differences in adverse outcomes } \\
\text { between the cohorts matched by age, } \\
\text { gender, ethnicity and calendar week } \\
\text { of infection }\end{array}$ \\
\hline 28 & Palmieri et al (49) & Italy & $\begin{array}{l}\text { 3, } 032 \text { deaths with COVID-19 of } \\
\text { whom } 6 \text { PLWH }\end{array}$ & $\begin{array}{l}\text { HIV was more common ( } 4 \text { cases) in } \\
\text { younger adults ( }<65 \text { years) }\end{array}$ & \\
\hline 29 & $\begin{array}{l}\text { Maggiolo et al } \\
(50)\end{array}$ & Italy & $\begin{array}{l}55 \text { HIV/ COVID-19 and } 69 \text { non- } \\
\text { COVID-19 PLWH from a population } \\
\text { of } 2,898 \text { PLWH }\end{array}$ & $\begin{array}{l}\text { Mortality rate } 7.2 \% \text {; Not compared to } \\
\text { the general population }\end{array}$ & $\begin{array}{l}\text { HIV does not appear to be a risk } \\
\text { factor for a severe COVID-19 disease }\end{array}$ \\
\hline 30 & Vizcarra et al (13) & $\begin{array}{l}\text { Madrid, } \\
\text { Spain }\end{array}$ & $\begin{array}{l}51 \text { HIV/ COVID- } 19 \text { vs } 1,288 \text { non- } \\
\text { COVID-19 HIV pts out of } 2,873 \\
\text { PLWH }\end{array}$ & $\begin{array}{l}\text { Lower mortality rates than the } \\
\text { general population ( } 4 \% \text { vs } 20 \% \text { ) }\end{array}$ & $\begin{array}{l}\text { PLWH "should receive the same } \\
\text { treatment as the general population" }\end{array}$ \\
\hline 31 & $\begin{array}{l}\text { Karmen-Tuohy et } \\
\text { al (51) }\end{array}$ & NYC, USA & $\begin{array}{l}21 \text { PLWH and } 42 \text { matched HIV- } \\
\text { negative controls out of } 2617 \text { HIV- } \\
\text { neg COVID-19 }\end{array}$ & $\begin{array}{l}\text { Similar mortality rate to HIV-negative } \\
\text { controls }(28.6 \% \text { vs } 23.8 \%)\end{array}$ & $\begin{array}{l}\text { HIV does not significantly impact } \\
\text { clinical outcomes }\end{array}$ \\
\hline
\end{tabular}




\begin{tabular}{|c|c|c|c|c|c|}
\hline 32 & Shalev et al (29) & NYC, USA & $\begin{array}{l}\text { 2,159 COVID-19 of whom } 31 \mathrm{HIV} / \\
\text { COVID-19 }\end{array}$ & 8 died & $\begin{array}{l}\text { Not compared to the general } \\
\text { population }\end{array}$ \\
\hline 33 & Jimenez et al (30) & $\begin{array}{l}\text { Madrid, } \\
\text { Spain }\end{array}$ & $\begin{array}{l}9 \text { HIV/ COVID-19 out of } 1,542 \\
\text { COVID-19 }\end{array}$ & 8 survived & \\
\hline 34 & $\begin{array}{l}\text { Altuntas Aydin et } \\
\text { al (52) }\end{array}$ & $\begin{array}{l}\text { Istanbul, } \\
\text { Turkey }\end{array}$ & $4 \mathrm{HIV} / \mathrm{COVID}-19$ out of $1,224 \mathrm{PLWH}$ & 1 died & $\begin{array}{l}\text { Comorbidities are important risk } \\
\text { factor in mortality in HIV/ COVID-19 } \\
\text { patients }\end{array}$ \\
\hline 35 & Guo et al (53) & $\begin{array}{l}\text { Wuhan, } \\
\text { China }\end{array}$ & 1,178 PLWH & 8 / 1178 were co-infected; 1 died & $\begin{array}{l}\text { Authors suggest HIV might reduce } \\
\text { COVID- } 19 \text { symptoms by reducing } \\
\text { immunopathology }\end{array}$ \\
\hline 36 & $\begin{array}{l}\text { Argenziano et al } \\
\text { (54) }\end{array}$ & NYC & $\begin{array}{l}21 \mathrm{HIV} / \mathrm{COVID}-19 \text { out of } 1000 \\
\text { consecutive patients with COVID-19 }\end{array}$ & 6 required $\mathrm{ICU}$ & $\begin{array}{l}\text { HIV was significantly associated with } \\
\text { mortality }\end{array}$ \\
\hline 37 & Calza et al (55) & Italy & $\begin{array}{l}26 \text { HIV/ COVID-19 out of } 756 \text { COVID- } \\
19\end{array}$ & All survived & $\begin{array}{l}\text { Comparable or milder clinical } \\
\text { presentation than the general } \\
\text { population }\end{array}$ \\
\hline 38 & Mondi et al (31) & Rome, Italy & $\begin{array}{l}604 \text { COVID-19 of whom } 5 \text { HIV/ } \\
\text { COVID-19 }\end{array}$ & All survived & $\begin{array}{l}\text { PLWH are not at increased risk of } \\
\text { severe COVID- } 19\end{array}$ \\
\hline 39 & Collins et al (56) & $\begin{array}{l}\text { Atlanta, } \\
\text { Georgia, } \\
\text { USA }\end{array}$ & $\begin{array}{l}20 \mathrm{HIV} / \mathrm{COVID}-19 \text { out of } 530 \text { COVID- } \\
19\end{array}$ & $\begin{array}{l}\text { Not compared to the general } \\
\text { population }\end{array}$ & $\begin{array}{l}3 \text { died; high prevalence of severe } \\
\text { COVID-19 was not observed among } \\
\text { PLWH }\end{array}$ \\
\hline 40 & $\begin{array}{l}\text { Fernandez- } \\
\text { Fuertes et al (17) }\end{array}$ & $\begin{array}{l}\text { Southern } \\
\text { Spain }\end{array}$ & 4 HIV/ COVID-19 out of 326 PLWH & 1 died; 3 mild disease & \\
\hline 41 & $\begin{array}{l}\text { Dandachi et al } \\
\text { (57) }\end{array}$ & USA & 286 HIV/ COVID-19 & $\begin{array}{l}27 \text { died; similar mortality rate to the } \\
\text { general population }\end{array}$ & $\begin{array}{l}\text { Low CD4 }(<200 \text { cells/ } \mu \text { l) associated } \\
\text { with poor outcomes }\end{array}$ \\
\hline 42 & $\begin{array}{l}\text { Nagarakanti et al } \\
\text { (22) }\end{array}$ & $\begin{array}{l}\text { New Jersey, } \\
\text { USA }\end{array}$ & $\begin{array}{l}23 \mathrm{HIV} / \mathrm{COVID}-19 \text { and } 23 \mathrm{HIV}- \\
\text { negative controls out of } 254 \mathrm{HIV} \text { - } \\
\text { negative COVID-19 pts }\end{array}$ & $\begin{array}{l}\text { Lower mortality than unmatched ( } 254 \\
\text { pts) }(13 \% \text { vs } 60 \%, p=0.001) \text { and } \\
\text { matched cohorts ( } 13 \% \text { vs } 26 \% \text {, } \\
p=0.261)\end{array}$ & $\begin{array}{l}\text { CD4 lymphopenia can be protective } \\
\text { against severe COVID-19; } 3 \text { patients } \\
\text { with AIDS survived }\end{array}$ \\
\hline 43 & Shekhar et al (58) & $\begin{array}{l}\text { New Mexico, } \\
\text { USA }\end{array}$ & 125 vs 5 HIV/ COVID-19 & $\begin{array}{l}\text { Not compared to the general } \\
\text { population }\end{array}$ & $\begin{array}{l}\text { All survived; PLWH may have a } \\
\text { milder COVID-19 disease; but only } \\
n=5\end{array}$ \\
\hline 44 & Parker et al (36) & $\begin{array}{l}\text { Cape Town, } \\
\text { South Africa }\end{array}$ & $\begin{array}{l}24 \text { HIV/ COVID-19 out of } 116 \text { COVID- } \\
19 \text { pts }\end{array}$ & $\begin{array}{l}\text { Similar death rate, } 6 \text { (25\%) vs } 22 \\
(25 \%)\end{array}$ & PLWH did not have higher mortality \\
\hline 45 & Ho et al (59) & NYC & $\begin{array}{l}72 \text { hospitalised HIV/ COVID-19 from } \\
93 \text { HIV/ COVID-19 pts }\end{array}$ & $\begin{array}{l}\text { Higher mortality rate }(26.3 \%) \text { than the } \\
\text { general population }(10.2 \%-24.5 \%\end{array}$ & $\begin{array}{l}\text { PLWH are at higher risk of a severe } \\
\text { COVID-19 disease, but not directly }\end{array}$ \\
\hline
\end{tabular}




\begin{tabular}{|c|c|c|c|c|c|}
\hline & & & & citing refs 2 and 5 from Table 1 ) & $\begin{array}{l}\text { comparable cohorts (HIV versus } \\
\text { community) }\end{array}$ \\
\hline 46 & Stoeckle et al (60) & NYC & $\begin{array}{l}30 \mathrm{HIV} / \mathrm{COVID}-19 \text { and } 90 \mathrm{HIV}- \\
\text { negative pts matched by age, gender } \\
\text { and ethnicity }\end{array}$ & $\begin{array}{l}\text { Death rate: } 2(7 \%) \text { in PLWH and } 14 \\
(16 \%) \text { in HIV-negative pts }\end{array}$ & $\begin{array}{l}\text { No significant difference in mortality } \\
\text { rate between PLWH and HIV- } \\
\text { negative cohort }\end{array}$ \\
\hline 47 & $\begin{array}{l}\text { Yamamoto et al } \\
\text { (61) }\end{array}$ & Tokyo, Japan & 83 COVID-19 vs 5 HIV/ COVID-19 & All survived & $\begin{array}{l}\text { Not compared to the general } \\
\text { population }\end{array}$ \\
\hline 48 & $\begin{array}{l}\text { Meyerowitz et al } \\
\text { (62) }\end{array}$ & $\begin{array}{l}\text { Massachuset } \\
\text { ts, USA }\end{array}$ & 36 confirmed HIV/ COVID-19 & 2 died & $\begin{array}{l}\text { Not compared to the general } \\
\text { population }\end{array}$ \\
\hline 49 & Kase et al (63) & $\begin{array}{l}12 \text { countries } \\
\text { in Central } \\
\text { and Eastern } \\
\text { Europe }\end{array}$ & $34 \mathrm{HIV} / \mathrm{COVID}-19$ & 2 died & Mild disease in majority of PLWH \\
\hline 50 & Härter et al (37) & Germany & $32 \mathrm{HIV} / \mathrm{COVID}-19$ & $\begin{array}{l}\text { Higher mortality rates than the } \\
\text { general population ( } 9 \% \text { vs } 3.7 \% \text { ) }\end{array}$ & $\begin{array}{l}\text { Numbers small: } 3 \text { died, } 2 \text { of whom } \\
\text { had undetectable viral load }\end{array}$ \\
\hline 51 & Calza et al (64) & $\begin{array}{l}\text { Bologna, } \\
\text { Italy }\end{array}$ & $\begin{array}{l}9 \text { PLWH with uncontrolled HIV out of } \\
31 \mathrm{HIV} / \mathrm{COVID}-19\end{array}$ & All (9) survived, 4 had AIDS. & $\begin{array}{l}\text { Uncontrolled HIV infection did not } \\
\text { seem to be associated with severe } \\
\text { COVID-19 }\end{array}$ \\
\hline 52 & Okoh et al (65) & NJ, USA & 27 HIV/ COVID-19 & 2 died & $\begin{array}{l}\text { Similar presentation to the general } \\
\text { population }\end{array}$ \\
\hline 53 & Childs et al (66) & London, UK & $18 \mathrm{HIV} / \mathrm{COVID}-19$ & 5 died & $\begin{array}{l}\text { Not compared to the general } \\
\text { population }\end{array}$ \\
\hline 54 & Madge et al (67) & London, UK & $18 \mathrm{HIV} / \mathrm{COVID}-19$ & $\begin{array}{l}3 \text { died; no patients required } \\
\text { ventilation or had a prolonged } \\
\text { COVID-19, hospital stay } 9 \text { days } \\
\text { (PLWH) vs } 7 \text { days (general hospital } \\
\text { population) }\end{array}$ & $\begin{array}{l}\text { Not compared to the general } \\
\text { population }\end{array}$ \\
\hline 55 & $\begin{array}{l}\text { Jewsbury et al } \\
(68)\end{array}$ & $\begin{array}{l}\text { Manchester, } \\
\text { UK }\end{array}$ & $16 \mathrm{HIV} / \mathrm{COVID}-19$ & 4 died & $\begin{array}{l}\text { PLWH with well controlled HIV may } \\
\text { have similar outcomes to the general } \\
\text { population }\end{array}$ \\
\hline 56 & Hu et al (69) & $\begin{array}{l}\text { Wuhan, } \\
\text { China }\end{array}$ & $12 \mathrm{HIV} / \mathrm{COVID}-19$ & 1 died & $\begin{array}{l}\text { Not compared to the general } \\
\text { population }\end{array}$ \\
\hline 57 & $\begin{array}{l}\text { Suwanwongse et } \\
\text { al (70) }\end{array}$ & NY, USA & 9 HIV/ COVID-19 & $\begin{array}{l}7 \text { died; PLWH with low CD4 count } \\
\text { may have higher mortality; high } \\
\text { mortality - suggest T cell } \\
\text { lymphopenia does not protect against } \\
\text { severe COVID-19 }\end{array}$ & $\begin{array}{l}\text { Not compared to the general } \\
\text { population }\end{array}$ \\
\hline 58 & Marimuthu et al & South India & $6 \mathrm{HIV} / \mathrm{COVID}-19$ & Not compared to the general & All survived; HIV does not increase \\
\hline
\end{tabular}




\begin{tabular}{|l|l|l|l|l|l|}
\hline & $(71)$ & & population & $\begin{array}{l}\text { the risk of a severe COVID-19 } \\
\text { disease }\end{array}$ \\
\hline 59 & $\begin{array}{l}\text { Swaminathan et al } \\
(72)\end{array}$ & $\begin{array}{l}\text { Philadelphia, } \\
\text { USA }\end{array}$ & 6 HIV/ COVID-19 & $\begin{array}{l}2(33 \%) \text { died; death rate of the } \\
\text { general population, 60\% }\end{array}$ & Numbers too small for comparison \\
\hline 60 & Ridgway et al (73) & $\begin{array}{l}\text { Chicago, } \\
\text { USA }\end{array}$ & 5 HIV/ COVID-19 & $\begin{array}{l}\text { Similar ICU admission rate to the } \\
\text { general population (20\%) }\end{array}$ & All survived \\
\hline 61 & $\begin{array}{l}\text { Benkovic et al } \\
(74)\end{array}$ & $\begin{array}{l}\text { Long Island, } \\
\text { USA }\end{array}$ & 4 HIV/ COVID-19 & All survived & $\begin{array}{l}\text { "uncomplicated COVID-19 in PLWH } \\
\text { can be managed with self-isolation at } \\
\text { home" }\end{array}$ \\
\hline
\end{tabular}

*Studies ranked by number of participants. Note studies may also appear in Table 1. aHR, adjusted hazard ratio with 95\% confidence intervals. Studies
\# 1;
2; $\quad 7$
17 ;
35
40;
47;
$49 ; \quad 51 ;$
54
are
pre-published
at the
time
of writing. 


\section{Figures}

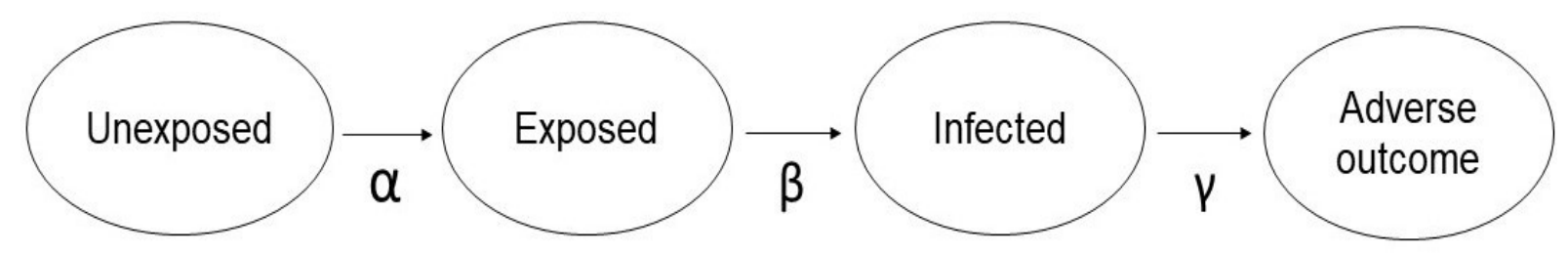

Figure 1. A model describing the probability of developing an adverse outcome from COVID-19.

$\alpha$, risk of exposure to COVID-19; $\beta$, risk of contracting COVID-19; $y$, risk of developing a severe infection resulting in an adverse outcome. 
medRxiv preprint doi: https://doi.org/10.1101/2020.12.04.20240218; this version posted December 7, 2020. The copyright holder for this preprint (which was not certified by peer review) is the author/funder, who has granted medRxiv a license to display the preprint in perpetuity.

It is made available under a CC-BY-NC 4.0 International license .

\section{References}

1. Wei WE, Li Z, Chiew CJ, Yong SE, Toh MP, Lee VJ. Presymptomatic Transmission of SARS-CoV-2 in Singapore. MMWR Morb Mortal Wkly Rep [Online]. 2020;69:411-5. Available from: dx.doi.org/10.15585/mmwr.mm6914e1 [Accessed october 2020].

2. www.who.int. COVID-19: vulnerable and high risk groups [Online]. 2020. Available from: https://www.who.int/westernpacific/emergencies/covid-19/information/high-risk-groups [Accessed October 2020].

3. BHIVA British HIV Association. Comment from BHIVA and THT on UK Government Guidance on Coronavirus (COVID-19), Social Distancing to Protect Vulnerable Adults and Shielding to Protect Extremely Vulnerable Adults. 2020. Available from: https://www.bhiva.org/comment-from-BHIVA-and-THT-on-UK-Government-guidance-onCoronavirus-COVID-19 [Accessed October 2020].

4. US Department of Health and Human Services. Interim Guidance for COVID-19 and Persons with HIV [Internet]. 2020. Available from: https://clinicalinfo.hiv.gov/guidelines/covid19-and-persons-hiv-interim-guidance/interim-guidance-covid-19-and-persons-hiv [Accessed November 2020].

5. Richardson S, Hirsch JS, Narasimhan M, et al. Presenting Characteristics, Comorbidities, and Outcomes among 5700 Patients Hospitalized with COVID-19 in the New York City Area. JAMA - J Am Med Assoc. 2020;323(20):2052-9.

6. Simon Collins. HIV is not linked to higher risk of COVID-19 in large New York cohort [Online]. HIV i-base. 2020. Available from: https://i-base.info/htb/37739 [Accessed November 2020].

7. Molina-Iturritza E, San-José-Muñiz I, Ganchegui-Aguirre M, et al. Coronavirus disease 2019 in patients with HIV in the province of Araba, Basque Country, Spain. AIDS [Online]. 2020;34(11). Available from:

https://journals.Iww.com/aidsonline/Fulltext/2020/09010/Coronavirus_disease_2019_in_patie nts_with_HIV_in.18.aspx [Accessed November 2020]

8. Sachdev D, Mara E, Hsu L, Scheer S, Rutherford G, Enanoria W, et al. COVID-19 Susceptibility and Outcomes among People Living with HIV in San Francisco. $J$ Acquir Immune Defic Syndr. Preprint, 2020 October 
9. Braunstein S, Lazar R, Wahnich A, Daskalakis DC, Blackstock OJ. COVID-19 infection among people with HIV in New York City: A population-level analysis of linked surveillance data, Clinical Infectious Diseases,2020, ciaa1793. Available from:https://doi.org/10.1093/cid/ciaa1793 [Accessed November 2020].

10. Cabello A, Zamarro B, Nistal S, et al. Covid-19 Disease in People Living With Hiv: a Multicenter Case-Series Study. Int J Infect Dis [Online]. 2020; Available from: https://doi.org/10.1016/j.ijid.2020.10.060 [Accessed November 2020].

11. Marcello RK, Dolle J, Grami S, et al. 12. Characteristics and outcomes of COVID-19 ptients in New york City's Public Hospital System. medRxiv, preprint.2020 [Online] Available from: doi: https://doi.org/10.1101/2020.05.29.20086645. [Accessed November 2020].

12. Tesoriero JM, Swain C-AE, Pierce JL, et al. Elevated COVID-19 outcomes among persons living with diagnosed HIV infection in New York State: Results from a population-level match of HIV, COVID-19, and hospitalization databases. medRxiv, preprint [Online]. 2020. Available from: https://doi.org/10.1101/2020.11.04.20226118 [Accessed November 2020].

13. Vizcarra P, Pérez-Elías MJ, Quereda C, et al. Description of COVID-19 in HIV-infected individuals: a single-centre, prospective cohort. Lancet HIV. 2020;7(8):e554-64.

14. Del Amo J, Polo R, Moreno S, et al. Incidence and Severity of COVID-19 in HIV-Positive Persons Receiving Antiretroviral Therapy $\square$ : A Cohort Study. Ann Intern Med. 2020;173(7):536-41.

15. Huang J, Xie N, Hu X, et al. Epidemiological, Virological and Serological Features of Coronavirus Disease 2019 (COVID-19) Cases in People Living With Human Immunodeficiency Virus in Wuhan: A Population-based Cohort Study. Clin Infect Dis. 2020; ciaa1186.

16. Inciarte A, Gonzalez-Cordon A, Rojas J, et al. Clinical characteristics, risk factors, and incidence of symptomatic coronavirus disease 2019 in a large cohort of adults living with HIV: a single-center, prospective observational study. AIDS. 2020;34(12):1775-80.

17. Fernandez-fuertes M, Rodriguez-pineda E, Fuentes-lopez A, et al. Incidence of COVID-19 among people living with HIV in Southern Spain. Research Square, preprint, 2020. Available from: DOI:10.21203/rs.3.rs-110312/v1

18. Laurence J. Why Aren't People Living with HIV at Higher Risk for Developing Severe Coronavirus Disease 2019 (COVID-19)? AIDS Patient Care STDS [Online]. 2020 May 14;34(6):247-8. Available from: https://doi.org/10.1089/apc.2020.29005.com [Accessed October 2020]. 
19. Boulle AA, Davies M, Hussey $\mathrm{H}$, et al. Risk factors for COVID-19 death in a population cohort study from the Western Cape Province, South Africa. Clin Infect Dis. 2020. Available from: https://doi.org/10.1093/cid/ciaa1198 [Accessed November 2020].

20. Bhaskaran K, Rentsch CT, Mackenna B, et al. HIV infection and COVID-19 death $\square$ : population-based cohort analysis of UK primary care data and linked national death registrations within the OpenSAFELY platform ( ${ }^{*}$ Joint principal investigators ) medRvix2, preprint, 2020. Available from: doi: https://doi.org/10.1101/2020.08.07.20169490

21. Geretti AM, Stockdale AJ, Kelly Sh, et al. Outcomes of COVID-19 related hospitalization among people with HIV in the ISARIC WHO Clinical Characterization Protocol (UK): a prospective observational study. Clin Infect Dis [Online]. 2020 Oct. Available from: https://doi.org/10.1093/cid/ciaa1605 [Accessed November 2020].

22. Nagarakanti SR, Okoh AK, Grinberg S, Bishburg E. Clinical outcomes of patients with COVID-19 and HIV coinfection. J Med Virol. 2020;19(August):1-7.

23. Toombs JM, Van den Abbeele K, Democratis J, Merricks R, Mandal AKJ, Missouris CG. COVID-19 in 3 people living with HIV in the United Kingdom. J Med Virol [Online]. 2020;0-3. Available from: http://dx.doi.org/10.1002/jmv.26178 [Accessed November 2020].

24. Park LS. COVID-19 in the largest US HIV cohort. In: COVID-19 in the largest US HIV cohort. 23rd International AIDS Conference abstract LBPEC23; 2020.

25. Gudipati S, Brar I, Murray S, McKinnon JE, Yared N, Markowitz N. Descriptive Analysis of Patients Living With HIV Affected by COVID-19. J Acquir Immune Defic Syndr. 2020;85(2):123-6.

26. Charre C, Icard V, Pradat P, et al. Coronavirus disease 2019 attack rate in HIV-infected patients and in preexposure prophylaxis users. AIDS. 2020;34(12):1765-70.

27. Miyashita H, Kuno T. Prognosis of coronavirus disease 2019 (COVID-19) in patients with HIV infection in New York City. HIV Med. 2020. Available from: https://doi.org/10.1111/hiv.12920 [Accessed November 2020].

28. D'Souza G, Springer G, Gustafson D, et al. COVID-19 symptoms and SARS-CoV-2 infection among people living with HIV in the US: the MACS/WIHS combined cohort study. HIV Res Clin Pract [Online]. 2020. Available from: https://doi.org/10.1080/25787489.2020.1844521

29. Shalev N, Scherer M, LaSota ED, et al. Clinical Characteristics and Outcomes in People Living With Human Immunodeficiency Virus Hospitalized for Coronavirus Disease 2019. Clin Infect Dis. 2020;24(April):23-6. 
30. Jiménez E, Fontán-Vela M, Valencia J, et al. Characteristics, complications and outcomes among 1549 patients hospitalised with COVID-19 in a secondary hospital in Madrid, Spain: A retrospective case series study. BMJ Open. 2020;10(11):1-10.

31. Mondi A, Cimini E, Colavita F, et al. COVID-19 in people living with HIV: Clinical implications of dynamics of the immune response to SARS-CoV-2. J Med Virol. 2020;(August):1-9.

32. Blanco JL, Ambrosioni J, Garcia F, et al. COVID-19 in patients with HIV: clinical case series. Lancet HIV. 2020;7(5):e314-6.

33. Goyal P, Choi JJ, Pinheiro LC, et al. Clinical Characteristics of Covid-19 in New York City. N Engl $J$ Med [Online]. 2020 Apr 17;382(24):2372-4. Available from: https://doi.org/10.1056/NEJMc2010419 [Accessed October 2020].

34. Sasset L, Di Meco E, Cavinato S, Cattelan AM. Coinfection of severe acute respiratory syndrome coronavirus 2 and HIV in a teaching hospital: still much to learn. AIDS. 2020;34(11):1694-6.

35. Karim F, Gazy I, Cele S, et al. HIV infection alters SARS-CoV-2 responsive immune parameters but not clinical outcomes in COVID-19 disease. medRxiv, preprint. 2020. Available from: doi: https://doi.org/10.1101/2020.11.23.20236828 [Accessed November 2020].

36. Parker A, Koegelenberg CFN, Moolla MS, et al. High HIV prevalence in an early cohort of hospital admissions with COVID-19 in Cape Town, South Africa. South African Med J. 2020;110(10):982-7.

37. Härter G, Spinner CD, Roider J, et al. COVID-19 in people living with human immunodeficiency virus: a case series of 33 patients. Infection [Online]. 2020;48(5):681-6. Available from: https://doi.org/10.1007/s15010-020-01438-z [Accessed November 2020].

38. Byrd KM, Beckwith CG, Garland JM, et al. SARS-CoV-2 and HIV coinfection: clinical experience from Rhode Island, United States. J Int AIDS Soc. 2020;23(7):1-7.

39. Etienne N, Karmochkine M, Slama L, et al. HIV infection and COVID-19: risk factors for severe disease. AIDS. 2020;34(12):1771-4.

40. Hadi YB, Naqvi SFZ, Kupec JT, Sarwari AR. Characteristics and outcomes of COVID-19 in patients with HIV: a multicentre research network study. AIDS. 2020;34(13).

41. Wang Z, Zheutlin A, Kao YH, et al. Hospitalised COVID-19 patients of the Mount Sinai Health System: A retrospective observational study using the electronic medical records. BMJ Open. 2020;10(10). 
42. Di Biagio A, Ricci E, Calza L, et al. Factors associated with hospital admission for COVID-19 in HIV patients. AIDS. 2020;34(13):1983-5.

43. Hassan Z, Hashim MJ, Khan G. Population risk factors for COVID-19 deaths in Nigeria at sub-national level. Pan Afr Med J. 2020;35(Supp 2):1-10.

44. Bastos L, Pocinho S, Machado A, et al. SARS-CoV-2 infection in HIV patients: we anticipated a worse scenario. $J$ Int Aids Soc. 2020;23(7, SI):122.

45. Gervasoni C, Meraviglia P, Riva A, et al. Clinical Features and Outcomes of Patients With Human Immunodeficiency Virus With COVID-19. Clin Infect Dis. 2020.

46. Isernia V, Julia Z, Le Gac S, et al. SARS-COV2 infection in 30 HIV-infected patients followed-up in a French University Hospital. Int J Infect Dis. 2020;101:49-51

47. Viraj V Patel. Clinical outcomes by HIV serostatus, CD4 count, and viral suppression among people hospitalized with COVID-19 in the Bronx, New York. In: AIDS 2020, 6 - 10 July [Online]. 2020.2 Available from: https://cattendee.abstractsonline.com/meeting/9289/presentation/3501

48. Sigel K, Swartz T, Golden E, et al. Coronavirus 2019 and People Living With Human Immunodeficiency Virus: Outcomes for Hospitalized Patients in New York City. Clin Infect Dis. 2020;12(10):e11007.

49. Palmieri L, Vanacore N, Donfrancesco C, et al. Clinical Characteristics of Hospitalized Individuals Dying with COVID-19 by Age Group in Italy. Journals Gerontol - Ser A Biol Sci Med Sci. 2020;75(9):1796-800.

50. Maggiolo F, Zoboli F, Arosio M, et al. SARS-CoV-2 infection in persons living with HIV: A single center prospective cohort. J Med Virol. 2020;(July):1-5.

51. Karmen-Tuohy S, Carlucci PM, Zervou FN, et al. Outcomes Among HIV-Positive Patients Hospitalized With COVID-19. J Acquir Immune Defic Syndr. 2020;85(1):6-10.

52. Altuntas Aydin O, Kumbasar Karaosmanoglu H, Kart Yasar K. HIV/SARS-CoV-2 coinfected patients in Istanbul, Turkey. J Med Virol. 2020;92(11):2288-90.

53. Guo W, Ming F, Dong Y, et al. A Survey for COVID-19 among HIV / AIDS Patients in Two Districts of Wuhan, China A Survey for COVID-19 among HIV / AIDS Patients in Two Districts of Wuhan , China. The Lancet Preprint, 2020. Available from: https://papers.ssrn.com/sol3/papers.cfm?abstract_id=3550029 [Accessed October 2020].

54. Argenziano MG, Bruc SL, Slate CL, et al. Characterization and clinical course of 1000 patients with coronavirus disease 2019 in New York: Retrospective case series. BMJ. 
2020;369(March).

55. Calza L, Bon I, Tadolini M, et al. COVID-19 in patients with HIV-1 infection: a single-centre experience in northern Italy. Infection [Online]. 2020;1(March). Available from: https://doi.org/10.1007/s15010-020-01492-7 [Accessed November 2020].

56. C Collins LF, Moran CA, Oliver NT, et al. Clinical characteristics, comorbidities and outcomes among persons with HIV hospitalized with coronavirus disease 2019 in Atlanta, Georgia. AIDS. 2020;34(12):1789-94.

57. Dandachi D, Geiger G, Montgomery MW, et al. Characteristics, Comorbidities, and Outcomes in a Multicentre Registry of Patients with HIV and Coronavirus Disease19, Clinical Infectious Diseases,2020 ciaa1339, Available from: https://doi.org/10.1093/cid/ciaa1339. [Accessed October, 2020].

58. Shekhar R, Barton A, Sheikh AB, Upadhyay S, Salas NM. Coronavirus Disease of 2019 in Patients With Well-Controlled Human Immunodeficiency Virus on Antiretroviral Therapy. $J$ Acquir Immune Defic Syndr. 2020;85(1):1-4.

59. Ho H, Peluso MJ, Margus C, et al. Clinical Outcomes and Immunologic Characteristics of Coronavirus Disease 2019 in People With Human Immunodeficiency Virus. J Infect Dis. 2020;(January 2019):4-9.

60. Stoeckle K, Johnston CD, Jannat-Khah DP, et al. COVID-19 in hospitalized adults with HIV. Open Forum Infect Dis. 2020;7(8):1-7.

61. Yamamoto S, Saito M, Nagai E, et al. Antibody response to SARS-CoV-2 in people living with HIV. J Microbiol Immunol Infect. preprint 2020. Available from: doi: 10.1016/j.jmii.2020.09.005 [Accessed October 2020].

62. Meyerowitz EA, Kim AY, Ard KL, et al. Disproportionate burden of coronavirus disease 2019 among racial minorities and those in congregate settings among a large cohort of people with HIV. AIDS. 2020;34(12):1781-7.

63. Kase K, Skrzat-Klapaczynska A,Vassilenko A, et al. The case series of 34 patients with COVID19 diagnosed with HIV infection from Central and Eastern European Countries - Euroguidelines in Central and Eastern Europe Network Group data. MedRxiv, preprint, 2020. Available from: doi: https://doi.org/10.1101/2020.09.16.20191528 [Accessed November 2020].

64. Calza L, Bon I, BorderiM, et al. Covid-19 Outcomes in Patients With Uncontrolled Hiv-1 Infection. JAIDS J Acquir Immune Defic Syndr. preprint, 2020. Available from: doi: 10.1097/QAI.0000000000002537 [Accessed November 2020].

65. Okoh AK, Bishburg E, Grinberg S, Nagarakanti S. COVID-19 Pneumonia in Patients With HIV: A Case Series. J Acquir Immune Defic Syndr. 2020;85(1):1-2.

66. Childs K, Post FA, Norcross C, et al. Hospitalized Patients With COVID-19 and Human 
Immunodeficiency Virus: A Case Series. Clin Infect Dis. 2020;71(8):2021-2..

68. Jewsbury S, Garner A, Houston J, et al. Characteristics and outcomes of inpatient COVID19 infections in people living with HIV. J Int Aids Soc. 2020;23(7, SI):121.

69. Hu Y, Ma J, Huang H, Vermund SH. Coinfection With HIV and SARS-CoV-2 in Wuhan, China: A 12-Person Case Series. J Acquir Immune Defic Syndr. 2020;85(1):1-5.

70. Suwanwongse K, Shabarek N. Variation in mortality of HIV/SARS-CoV-2 coinfected patients in the Bronx, New York City. J Med Virol. 2020;1-3.

71. Marimuthu J, Kumar BS, Gandhi P. A. HIV and SARS CoV-2 coinfection: A retrospective, record-based, case series from South India. J Med Virol. 2020;1-3.

72. Swaminathan N, Moussa P, Mody N, Bryan Lo K, Pattaroyo GA. COVID-19 in HIV infected patients: A Case series and Literature Review. J Med Virol [Online]. 2020;(November). Available from: http://www.ncbi.nlm.nih.gov/pubmed/33200823 [Accessed November 2020].

73. Ridgway JP, Schmitt J, Friedman E, et al. HIV Care Continuum and COVID-19 Outcomes Among People Living with HIV During the COVID-19 Pandemic, Chicago, IL. AIDS Behav [Online]. 2020;24(10):2770-2. Available from: https://doi.org/10.1007/s10461-020-02905-2 [Accessed November 2020].

74. Benkovic S, Kim M, Sin E. Four cases: Human immunodeficiency virus and novel coronavirus 2019 Co-infection in patients from Long Island, New York. J Med Virol [Online]. 2020;92(11):2338-40. Available from: https://doi.org/10.1002/jmv.26029 [Accessed November 2020]. 